\title{
PENGARUH PELANTIKAN KABINET KERJA HASIL RESHUFFLE JILID II TERHADAP HARGA SAHAM LQ-45
}

\author{
Aulia Hatmanti \& Bambang Sudibyo \\ Universitas Gadjah Mada, Indonesia \\ Email: auliahatmanti@gmail.com
}

\begin{abstract}
Abstrak: Pengaruh Pelantikan Kabinet Kerja Hasil Reshuffle Jilid II terhadap Harga Saham LQ-45. Tujuan dari penelitian ini adalah untuk melihat pengaruh peristiwa politik -- pelantikan Kabinet Kerja hasil reshuffle jilid II -- terhadap harga saham yang terdaftar dalam kelompok saham LQ-45. Penelitian ini menggunakan metode studi peristiwa untuk melihat adanya reaksi pasar yang dapat dilihat dari adanya abnormal return pada saham. Abnormal return pada penelitian ini dihitung menggunakan meanadjusted model. Berdasarkan hasil uji beda t-test satu sisi, terdapat abnormal return positif yang signifikan pada event day $(\mathrm{t})$ dan $\mathrm{t}+3$. Uji beda rata-rata menggunakan paired sample t-test yang dilakukan untuk melihat perbedaan rata-rata abnormal return pada 5 hari sebelum dan 5 hari sesudah peristiwa tidak menunjukkan adanya hasil yang signifikan. Berdasarkan hasil tersebut, dapat disimpulkan bahwa peristiwa politik berupa pelantikan Kabinet Kerja hasil reshuffle jilid II merupakan good news bagi investor.
\end{abstract}

Kata kunci: studi peristiwa, abnormal return, LQ-45, peristiwa politik

\begin{abstract}
The Impact of the Inauguration of $2^{\text {nd }}$ Reshuffled Cabinet on LQ-45 Stock Prices. The purpose of this research is to observe the impact of the political event -the inauguration of $2^{\text {nd }}$ reshuffled cabinet -- to LQ- 45 group's stock prices. This study used event study method to identify the market reaction that can be seen from the abnormal return on the stock prices. The abnormal return is calculated using meanadjusted model. T-test indicates that there is a significant positive abnormal return on event day $(t)$ and $t+3$. Besides, paired sample t-test was conducted to see the difference in the average abnormal return in 5 days before and five days after the events didn't show any significant results. Based on these results, it can be concluded that the inauguration of $2^{\text {nd }}$ reshuffled cabinet is good news for investors.
\end{abstract}

Keywords: event study, abnormal return, LQ-45, political events

\section{PENDAHULUAN}

Pasar modal memiliki peran besar bagi perekonomian suatu negara karena pasar modal memiliki dua fungsi sekaligus, yaitu fungsi ekonomi dan fungsi keuangan (Hartono, 2014). Pasar modal dikatakan memiliki fungsi ekonomi karena pasar menyediakan fasilitas atau wahana yang mempertemukan dua kepentingan yaitu pihak yang memiliki kelebihan dana (investor) dan pihak yang memerlukan dana (issuer). Dengan adanya pasar modal maka pihak yang memiliki kelebihan dana dapat menginvestasikan dana tersebut dengan harapan memperoleh imbalan (return) berupa dividen, sedangkan pihak issuer (dalam hal ini perusahaan) dapat memanfaatkan dana tersebut untuk kepentingan investasi tanpa harus menunggu tersedianya dana dari kegiatan 
operasi perusahaan. Pasar modal dikatakan memiliki fungsi keuangan, karena pasar modal memberikan kemungkinan dan kesempatan memperoleh imbalan (return) bagi pemilik dana, sesuai dengan karakteristik investasi yang dipilih.

Keberhasilan pasar modal dipengaruhi oleh beberapa faktor, di antaranya ketersediaan sekuritas, permintaan akan sekuritas, masalah hukum dan peraturan, keberadaan lembaga yang mengatur dan mengawasi kegiatan pasar modal dan berbagai lembaga yang memungkinkan dilakukan transaksi secara efisien, dan kondisi politik dan ekonomi suatu negara (Husnan, 2008:8-9).

Pengaruh lingkungan non ekonomi, meski tidak terkait secara langsung dengan dinamika yang terjadi di pasar modal, tidak dapat dipisahkan dari aktivitas bursa saham Suryawijaya dan Faizal (1998). Salah satu contohnya adalah peristiwa politik yang terjadi di suatu negara. Sebagai instrumen keuangan yang memiliki peranan penting dalam perekonomian Indonesia, pasar modal tidak terlepas dari pengaruh lingkungan politik, bahkan tak jarang peristiwa politik menjadi faktor penyebab naik-turunnya harga saham. Tak hanya di bursa saham Indonesia, hal tersebut juga terjadi di bursa saham seluruh dunia. Sehubungan dengan hal tersebut, investor tentunya akan menggunakan informasi terkait kebijakankebijakan politik yang diambil oleh pemerintah suatu negara sebagai pertimbangan sebelum mengambil keputusan terkait investasinya.

Pasar modal Indonesia termasuk dalam kategori bentuk setengah kuat atau biasa disebut semi strong-form (Strong, 2001:213).
Untuk itu, harga sekuritas di pasar modal Indonesia telah secara penuh mencerminkan semua informasi yang dipublikasikan. Pasar akan bereaksi apabila terjadi pengumuman tentang suatu peristiwa yang memiliki kandungan informasi.

Kecepatan reaksi pasar terhadap suatu peristiwa akan menentukan efisien atau tidaknya suatu pasar. Pasar yang efisien adalah pasar di mana harga semua sekuritas yang diperdagangkan telah mencerminkan semua informasi yang tersedia (Tandelilin, 2010). Pada pasar yang efisien, harga sekuritas akan cepat terevaluasi ketika terdapat informasi penting yang berkaitan dengan sekuritas.

Abnormal return merupakan indikator yang digunakan untuk mengukur reaksi pasar akibat terjadi suatu peristiwa tertentu. Abnormal return merupakan selisih antara return yang sesungguhnya terjadi (actual return) dengan return yang diharapkan investor (expected return). Bila suatu peristiwa tertentu yang terjadi mengandung suatu informasi baik (good news) akan berdampak terhadap kenaikan abnormal return, dan akan berdampak penurunan abnormal return bila informasi tersebut dianggap buruk (bad news) (Tandelilin, 2010).

Teori tersebut sejalan dengan beberapa penelitian yang telah dilakukan. Penelitian Chandra (2013) menunjukkan hasil bahwa peningkatan harga bahan bakar minyak yang tergolong bad news memperoleh reaksi berupa negative abnormal return dari pasar. Penelitian lain yang dilakukan oleh Rahayu (2007) untuk meneliti reaksi pasar modal terhadap peristiwa reshuffle terbatas kabinet Indonesia Bersatu oleh Presiden Susilo 
Bambang Yudhoyono pada tahun 2005. Dari hasil penelitiannya, pasar modal bereaksi positif dan signifikan terhadap pengumuman reshuffle kabinet terbatas. Hal tersebut dikarenakan menteri-menteri baru pilihan SBY akan mampu memperbaiki permasalahan ekonomi pada saat itu. Hasil penelitian ini juga sejalan dengan teori bahwa good news akan memperoleh reaksi berupa positive abnormal return. Abnormal return dapat dihitung dengan menggunakan rumus:

$A R_{i t}=R_{i t}-E\left[R_{i t}\right]$

Keterangan:

$\mathrm{AR}_{\mathrm{it}}=$ abnormal return saham $\mathrm{i}$ pada hari $\mathrm{t}$.

$\mathrm{R}_{\mathrm{it}}=$ actual return untuk saham i pada hari $\mathrm{t}$. $E\left[R_{i t}\right]=$ expected return untuk saham i pada hari t.

Event study merupakan teknik yang paling banyak digunakan untuk melakukan penelitian di bidang keuangan. Event study merupakan sebuah teknik riset yang memungkinkan peneliti untuk menilai dampak dari suatu peristiwa tertentu terhadap harga saham perusahaan (Bodie et.al., 2011). Menurut Hartono (2014), event study merupakan studi yang mempelajari pengaruh dari suatu peristiwa terhadap reaksi pasar yang informasinya dipublikasikan dalam bentuk pengumuman. Reaksi pasar dapat dilihat melalui perubahan harga sekuritas dengan menggunakan proksi abnormal return. Apabila suatu peristiwa memiliki kandungan informasi, maka pasar akan bereaksi pada saat peristiwa tersebut diumumkan. Sebaliknya apabila suatu peristiwa tidak memiliki kandungan informasi, maka pasar akan tidak akan bereaksi pada saat peristiwa tersebut diumumkan (tidak akan terdapat abnormal return).
Beberapa penelitian telah dilakukan untuk Nimkhunthod (2007) menemukan terdapat pengaruh peristiwa pergantian pemerintahan yang terjadi selama tahun 1975-2006 terhadap tingkat return saham di Thailand, di mana tingkat return saham secara umum bernilai positif signifikan pada minggu pertama hingga minggu kedua setelah peristiwa. Nippani dan Arize (2005) yang melakukan penelitian untuk mengetahui dampak pemilihan presiden di Amerika Serikat bagi pasar modal di Kanada dan Meksiko menemukan bahwa peristiwa tersebut memberikan dampak negatif bagi pasar modal baik di Kanada maupun di Meksiko selama periode peristiwa. Asri (1996) melakukan penelitian tentang reaksi pasar modal Amerika terhadap peristiwa pengunduran diri Perdana Menteri Takeshita dan menemukan bahwa terdapat abnormal return yang signifikan neegatif pada $\mathrm{t}+2$ dan $\mathrm{t}+7$.

Penelitian terkait pengaruh kondisi politik terhadap harga saham di Indonesia juga telah banyak dilakukan. Salah satunya penelitian yang dilakukan oleh Suryawijaya dan Setiawan (1997) yang meneliti tentang reaksi pasar modal Indonesia terhadap peristiwa 27 Juli 1996 menemukan bahwa terdapat negative abnormal return yang signifikan pada event date, namun hasil analisis uji beda rata-rata tidak menunjukkan hasil yang signifikan.

Reshuffle Kabinet Kerja Jilid II yang dilaksanakan pada tanggal 27 Juli 2016 merupakan salah satu peristiwa politik berskala nasional yang cukup menyita perhatian masyarakat beberapa waktu yang lalu. Untuk kedua kalinya, Presiden Jokowi secara resmi kembali mengubah susunan 
Kabinet Kerja, setelah sebelumnya pada tanggal 12 Agustus 2015, Jokowi juga telah melakukan perubahan susunan pada kabinet bentukannya tersebut. Dalam reshuffle kali ini, terdapat 13 posisi menteri yang dirombak. Dari 13 posisi tersebut, 4 posisi diisi oleh menteri lama yang bergeser posisinya, sedangkan 9 posisi lainnya dijabat oleh nama-nama baru. Dari 9 nama baru yang masuk, 4 di antaranya berasal dari kalangan parpol, sedangkan sisanya berasal dari kalangan professional.

Dalam kabinet baru hasil perombakan kali ini, Sri Mulyani menjadi nama baru yang paling disorot saat masuk ke dalam jajaran menteri. Pengangkatan Sri Mulyani dinilai membawa angin segar bagi perekonomian Indonesia, mengingat kredibilitas Sri Mulyani tidak dapat diragukan lagi. Kembalinya Sri Mulyani ke Indonesia untuk menjabat posisi Menteri Keuangan diduga akan meningkatkan capital-inflow bagi perusahaan-perusahaan di Indonesia. Hal tersebut dikarenakan Sri Mulyani dianggap akan mampu membawa perekonomian Indonesia ke arah yang leih baik. Dari sisi pengalaman, Sri Mulyani tidak perlu diragukan lagi. Sebelumnya, Sri Mulyani menjabat sebagai Managing Director dan Chief Operating Officers Bank Dunia. Kariernya di dunia internasional pun diakui dunia, terbukti Sri Muyani merupakan satusatunya wanita Indonesia yang masuk dalam jajaran perempuan paling berpengaruh di dunia atau Power Women 2016 versi majalah Forbes, dan menduduki peringkat ke-37. Sri Mulyani sebelumnya juga pernah menjabat sebagai Menteri Keuangan di era Presiden Susilo Bambang Yudhoyono.
Peristiwa terkait pelantikan kabinet hasil reshuffle jilid II selanjutnya dapat dikatakan sebagai good news, oleh karena itu disusunlah hipotesis alternatif sebagai berikut:

H1: Peristiwa pelantikan Kabinet Kerja hasil reshuffle jilid II memberikan abnormal return yang positif bagi investor.

H2: Rata-rata abnormal return setelah peristiwa pelantikan Kabinet Kerja hasil reshuffle jilid II lebih positif dibandingkan sebelum peristiwa.

\section{METODE}

Dalam penelitian ini, metode yang digunakan adalah event study. Hal ini disebabkan penelitian ini bertujuan untuk mengetahui pengaruh suatu peristiwa terhadap harga saham. Peristiwa yang akan diteliti dalam penelitian ini adalah pelantikan Kabinet Kerja hasil reshuffle jilid II yang dilaksanakan pada tanggal 27 Juli 2016. Peristiwa ini merupakan salah satu peristiwa politik yang berskala nasional dan disorot oleh berbagai media.

Populasi penelitian ini adalah seluruh perusahaan yang terdaftar di Bursa Efek Indonesia pada periode penelitian. Sampel yang digunakan dalam penelitian ini adalah perusahaan yang sahamnya secara konsisten termasuk dalam LQ-45 pada periode Februari - Agustus 2016. Menurut Hartono (2014), pasar modal di Indonesia sebagian besar sekuritas-nya kurang aktif diperdagangkan, sehingga masih tergolong thin market. Untuk itu, IHSG yang mencakup seluruh saham yang diperdagangkan dianggap kurang tepat digunakan sebagai indikator pasar modal. Kemudian, dibentuklah alternatif indeks lain, yaitu indeks LQ-45, yang terdiri dari 45 saham yang 


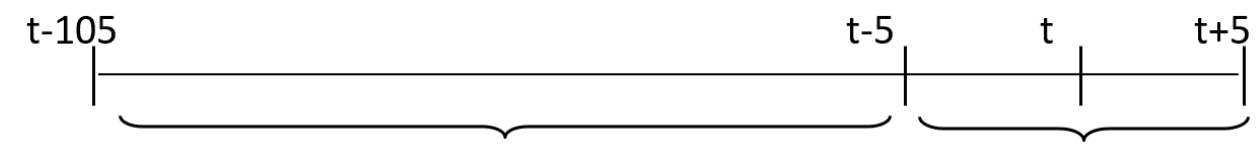

Gambar 1. Periode Penelitian

$$
\begin{array}{ll}
\mathrm{t}-105 & =18 \text { Februari } 2016 \\
\mathrm{t}-5 & =20 \text { Juli } 2016 \\
\mathrm{t} & =27 \text { Juli } 2016 \\
\mathrm{t}+5 & =3 \text { Agustus } 2016
\end{array}
$$

paling aktif diperdagangkan di pasar modal, paling likuid, dan memiliki nilai kapitalisasi besar sebagai indikator likuidasi. Penggunaan saham perusahaan-perusahaan yang terdaftar dalam indeks ini dianggap dapat mewakili populasi pasar secara keseluruhan.

Jenis data yang digunakan dalam penelitian ini adalah data kuantitatif, yaitu harga saham emiten yang menjadi sampel penelitian. Sumber data yang digunakan adalah data sekunder yang berupa data dan informasi yang diterbitkan oleh pihak lain, dalam hal ini Bursa Efek Indonesia (www.idx.co.id) serta PT. Kustodian Sentral Efek Indonesia (KSEI) (www.ksei.co.id).

Panjang dari periode estimasi berkisar antara 100 hari sampai 250 hari untuk data harian, sedangkan untuk periode kejadian apabila data yang digunakan adalah return harian, maka periode pengamatan yang dilakukan berkisar antara 3 hari sampai 121 hari tergantung pada nilai ekonomis suatu pengumuman peristiwa (Hartono, 2014). Penggunaan periode peristiwa yang panjang menunjukkan peneliti tidak percaya bahwa peristiwa akan diantisipasi secara cepat oleh pasar, sesuai dengan asumsi pasar efisien (McWilliams dan Siegel, 1997). Untuk itu, dalam penelitian ini, pengamatan pada periode estimasi dilakukan selama 100 hari bursa, sedangkan pada periode kejadian, pengamatan dilakukan selama 11 hari, yakni 5 hari bursa sebelum peristiwa, pada tanggal peristiwa, dan 5 hari bursa setelah peristiwa (Gambar 1). Penetapan lamanya periode peristiwa selama 5 hari bursa juga dilakukan untuk meminimalisir adanya bias akibat peristiwa lain di sekitar tanggal peristiwa. Tanggal peristiwa (event day) ditetapkan pada saat pelantikan Kabinet Kerja hasil reshuffle kabinet jilid II yang dilaksanakan pada tanggal 27 Juli 2016.

Daftar perusahaan yang masuk dalam indeks LQ-45 diperbarui setiap enam bulan sekali, yaitu pada awal bulan Februari dan Agustus. Dari 45 perusahaan yang ada, pada bulan Agustus 2016 terdapat 1 perusahaan yang keluar dari kelompok LQ-45 yakni Tower Bersama Infrastructure, Tbk. yang kemudian digantikan oleh Elnusa, Tbk.

Perusahaan-perusahaan yang memiliki confounding effects seperti merger, akuisisi, stock split, pengumuman dividend dan lain sebagainya pada periode estimasi akan dikeluarkan dari sampel karena dapat menyebabkan studi peristiwa menjadi bias dan mempengaruhi validitas penelitian. Khusus untuk perusahaan dengan confounding effect yang berupa stock split, 
Tabel 1. Total sampel penelitian

\begin{tabular}{|c|c|}
\hline Kriteria & Jumlah Perusahaan \\
\hline $\begin{array}{l}\text { Perusahaan yang secara konsisten masuk dalam kelompok LQ-45 } \\
\text { pada periode Februari-Agustus } 2016 \\
\text { (-) Perusahaan dengan confounding effects selama periode } \\
\text { peristiwa } \\
\text { (-) Perusahaan dengan confounding effects berupa stock split } \\
\text { selama periode estimasi }\end{array}$ & $\begin{array}{l}44 \\
(5) \\
\text { (1) }\end{array}$ \\
\hline Total Sampel & 38 \\
\hline
\end{tabular}

baik pada periode estimasi maupun periode peristiwa akan dieliminasi. Hal ini dilakukan untuk meningkatkan kehati-hatian pengujian, karena perusahaan yang mengalami stock split akan menghasilkan data harga saham yang terlalu ekstrem. Data yang digunakan diperoleh dari website Bursa Efek Indonesia (www.idx.co.id) serta PT. Kustodian Sentral Efek Indonesia (KSEI) (www.ksei.co.id). Dari kriteria yang telah ditetapkan, total perusahaan yang memenuhi kriteria sejumlah 38 perusahaan.

\section{Pengujian Hipotesis 1}

Dalam menghitung expected return, terdapat tiga model perhitungan yaitu dengan menggunakan mean adjusted model, market-adjusted model, atau single-index market model. Penelitian Brown dan Warner (1985) menunjukkan bahwa mean adjusted model tidak kalah baiknya dengan marketadjusted model dan single-index market model. Oleh karena itu, ketiga metode tersebut dapat diterapkan saat melakukan event study pada pasar modal Indonesia. Penelitian ini menggunakan mean adjusted model, di mana expected return dianggap bernilai konstan yang sama dengan rerata actual return selama periode estimasi.
Perhitungan expected return menggunakan mean adjusted model.

Data yang berdistribusi normal merupakan syarat dilakukannya pengujian parametrik berupa t-test. Oleh karena itu, uji normalitas data perlu dilakukan, salah satu metodenya adalah dengan menggunakan Kolmogorov-Smirnov test, untuk melihat apakah data berdistribusi normal atau tidak (Kim, 2015). Hal tersebut juga sejalan dengan penelitian yang dilakukan oleh Suryanto (2015) yang meneliti pengaruh pengumuman investment grade terhadap perusahaan-perusahaan di Indonesia. Pengujian parametrik tidak dapat dilakukan pada data yang tidak berdistribusi normal. Untuk itu, apabila data terbukti berdistribusi normal, maka pengujian parametrik menggunakan t-test pada abnormal return dapat dilakukan, sedangkan apabila data tidak berdistribusi normal, maka dapat dilakukan transformasi data, trimming, atau bootstrapping untuk mengubah distribusi data menjadi distribusi normal (Keselman et.al, 2002).

Pengujian abnormal return positif pada periode pengamatan menggunakan meanadjusted model yang dikutip dari Hartono (2010) dengan ditambahkan uji normalitas. Langkah-langkahnya adalah menghitung 
Tabel 2. Hasil Perhitungan Kolmogorov-Smirnov

\begin{tabular}{cc}
\hline Periode & KS hitung \\
\hline Sebelum Peristiwa & 0,15457 \\
Setelah Peristiwa & 0,20507 \\
\hline
\end{tabular}

actual return setiap saham yang dijadikan sampel penelitian, menghitung expected return, menghitung abnormal return saham selama periode peristiwa, menghitung cumulative abnormal return (CAR), menghitung average abnormal return (AAR), Menghitung cumulative average abnormal return (CAAR) seluruh saham, dan melakukan pengujian normalitas data.

Pengujian statistik terhadap abnormal return dilakukan dengan langkah:

1. Menghitung standar error estimasi untuk saham selama periode T dalam estimasi.

$$
\begin{aligned}
& \sigma_{i}=\sqrt{\frac{\sum_{\mathrm{k}=1}^{\top}\left(\mathrm{R}_{\mathrm{ij}}-\overline{\mathrm{R}_{\mathrm{i}}}\right)^{2}}{\mathrm{~T}}} \\
& \sigma_{\mathrm{i}}=\text { standar error estimasi } \\
& \mathrm{T}=\text { jumlah hari di periode estimasi }
\end{aligned}
$$

2. Menghitung standardized abnormal return $\left(\mathrm{SAR}_{\mathrm{it}}\right)$ untuk tiap-tiap sekuritas untuk masing-masing tanggal di perioda peristiwa.

$\mathrm{SAR}_{\mathrm{it}}=\frac{A R_{i \mathrm{t}}}{\sigma_{\mathrm{i}}}$

3. Menghitung standardized abnormal return $\left(\mathrm{SAR}_{\mathrm{t}}\right)$ seluruh sekuritas untuk masing-masing tanggal di periode peristiwa atau t-hitung.

$t_{t}=S_{A} R_{t}=\frac{\sum_{i=1}^{n} S A R_{i t}}{\sqrt{n}}$

4. Membandingkan nilai t-hitung dan ttabel.

Tingkat signifikansi yang digunakan adalah 0,05 . Apabila nilai t-hitung $>\mathrm{t}$ tabel pada periode setelah peristiwa, maka hipotesis alternatif diterima.

\section{Pengujian Hipotesis 2}

Pengujian untuk mengetahui adanya ratarata abnormal return yang positif pada periode setelah peristiwa dilakukan dengan menggunakan paired sample t-test terhadap AAR sebelum dan setelah peristiwa yang dihitung menggunakan Microsoft Excel. Dalam pengujian ini nilai $\alpha$ yang digunakan adalah 0,05 . Hipotesis alternatif diterima apabila $p$ value one tailed-test< nilai $\alpha(0,05)$.

\section{HASIL DAN PEMBAHASAN}

Uji normalitas data dilakukan dengan terlebih dahulu menghitung KolmogorovSmirnov (KS) hitung. Tabel 1 merupakan hasil perhitungan KS hitung.

Nilai KS tabel untuk $n=5$ dan $\alpha=5 \%$ adalah 0,565 , sedangkan hasil perhitungan menunjukkan bahwa pada periode sebelum peristiwa nilai KS hitung adalah sebesar 0,15457 dan nilai KS hitung pada periode setelah peristiwa adalah 0,20507. Baik pada periode sebelum maupun setelah peristiwa, nilai KS hitung < KS tabel. Hal tersebut menunjukkan bahwa data berdistribusi normal. Untuk itu, pengujian parametrik menggunakan $t$-test dapat dilakukan.

\section{Hasil Pengujian Hipotesis 1}

Hipotesis pertama akan dilakukan untuk menguji adanya abnormal return positif signifikan pada periode sesudah peristiwa. Pengujian dilakukan dengan menggunakan $t$ test. Tabel 2 merupakan hasil pengujian hipotesis. 
Tabel 3. Hasil Perhitungan Average Abnormal Return, Cumulative Average Abnormal Return, dan t-hitung

\begin{tabular}{ccccc}
\hline $\begin{array}{c}\text { Periode } \\
\text { Peristiwa }\end{array}$ & Tanggal Peristiwa & AAR & CAAR & t-hitung \\
\hline t-5 & 20 Juli 2016 & 0,00477 & 0,00477 & 1,58322 \\
t-4 & 21 Juli 2016 & $-0,01287^{*}$ & $-0,00809$ & $-3,41411$ \\
t-3 & 22 Juli 2016 & $-0,00294$ & $-0,01103$ & $-1,16042$ \\
t-2 & 25 Juli 2016 & 0,00277 & $-0,00826$ & 0,96189 \\
t-1 & 26 Juli 2016 & $-0,00272$ & $-0,01098$ & $-0,32833$ \\
T & 27 Juli 2016 & $0,01018^{*}$ & $-0,00081$ & 3,49413 \\
t+1 & 28 Juli 2016 & 0,00471 & 0,00390 & 1,03589 \\
t+2 & 29 Juli 2016 & $-0,01871^{*}$ & $-0,01481$ & $-5,23642$ \\
t+3 & 1 Agustus 2016 & $0,02329 *$ & 0,00848 & 6,91406 \\
t+4 & 2 Agustus 2016 & $-0,00382$ & 0,00467 & $-1,30362$ \\
t+5 & 3 Agustus 2016 & $-0,00407$ & 0,00060 & $-0,97351$ \\
\hline
\end{tabular}

* signifikan pada level $5 \%$

Nilai t-tabel adalah sebesar 2,026. Berdasarkan hasil perhitungan yang disajikan dalam tabel di atas, dapat dilihat bahwa terdapat abnormal return yang signifikan pada $t-4$, event day $(t), t+2$, dan $t+3$. Nilai $t$ hitung pada $\mathrm{t}-4$ dan $\mathrm{t}+2$ bernilai negatif sebesar $-3,41411$ dan $-5,23642$, sedangkan nilai t hitung pada event day dan $\mathrm{t}+3$ bernilai positif sebesar 3,49413 dan 6,91406. Adanya abnormal return yang bernilai positif signifikan pada periode setelah peristiwa menunjukkan bahwa hipotesis alternatif yang menyatakan bahwa peristiwa pelantikan Kabinet Kerja hasil reshuffle jilid II memberikan abnormal return yang positif kepada investor diterima. Hasil penelitian ini sejalan dengan teori yang menyatakan bahwa informasi yang dianggap baik akan direspon secara positif oleh pasar, ditunjukkan dengan adanya abnormal return di sekitar periode penelitian, namun apabila informasi dianggap kurang baik maka akan direspon secara negatif oleh pasar ditunjukkan dengan abnormal return yang bersifat negatif (Tandelilin, 2010). Pelantikan
Sri Mulyani sebagai Menteri Keuangan dianggap sebagai good news karena Sri Mulyani dengan pengalamannya dianggap akan mampu membawa perekonomian Indonesia ke arah yang lebih baik melalui kebijakan-kebijakan yang nantinya akan dikeluarkan.

Peneliti menganggap abnormal return yang bernilai negatif signifikan pada $t-4$ merupakan bukti kekecewaan publik terhadap sikap presiden yang mengisyaratkan reshuffle batal dilakukan. Setelah kurang lebih 5 bulan isu reshuffle muncul, publik berharap nantinya reshuffle benar-benar dilaksanakan. Apabila presiden mengganti menteri yang selama ini kinerjanya kurang baik diharapkan kinerja pemerintahan akan semakin baik. Meski begitu, berita tersebut tidak berpengaruh cukup lama kepada pasar modal. Isu terkait reshuffle kabinet kembali menguat. Hal tersebut ditunjukkan oleh abnormal return pada t-3 hingga t-2 yang kembali bergerak ke arah positif. 


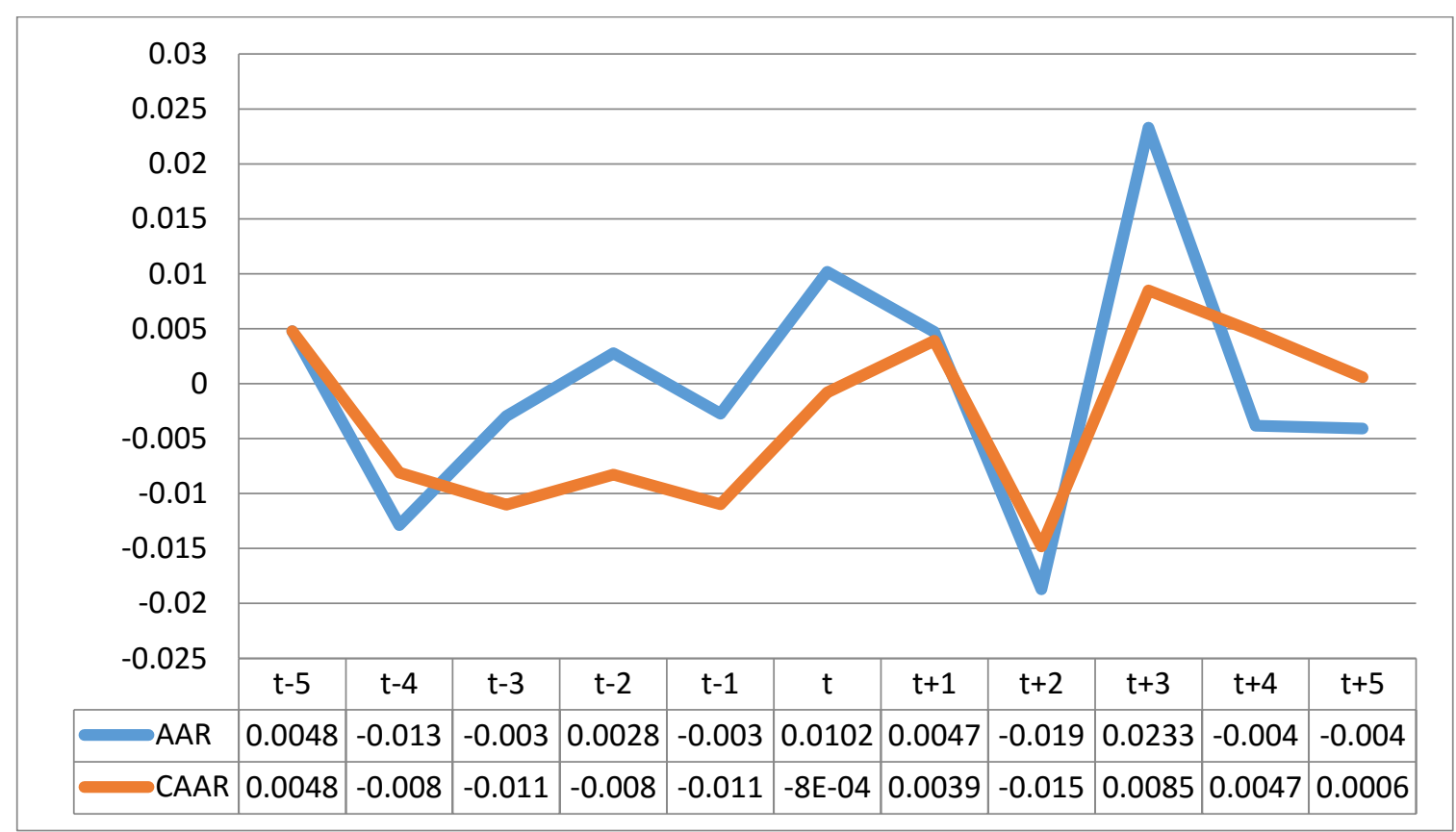

Gambar 2. Grafik Average Abnormal Return dan Cumulative Abnormal Return

Abnormal return bergerak positif dan signifikan secara statistik pada tanggal dilaksanakannya pelantikan Kabinet Kerja hasil reshuffle jilid II pada tanggal 27 Juli 2016. Hal tersebut menunjukkan bahwa pasar menganggap peristiwa pelantikan Kabinet Kerja hasil reshuffle jilid II merupakan good news, sehingga disambut dengan baik oleh pelaku pasar. Publik menaruh harapan bahwa perombakan kabinet ini dapat lebih menstimulus realisasi kebijakan-kebijakan pemerintah yang telah dikeluarkan. Menteri baru, khususnya Sri Mulyani yang menjabat sebagai Menteri Keuangan dinilai akan mampu membawa Indonesia melaju di tengah gejolak perekonomian dunia. Alasannya, dari sisi pengalaman, Sri Mulyani tidak perlu diragukan lagi. Sri Mulyani pernah menjabat sebagai Menteri Keuangan pada era pemerintahan Susilo Bambang Yudhoyono. Selain itu, Sri Mulyani juga pernah menjabat sebagai Managing Director dan Chief Operating Officers Bank Dunia selama enam tahun.

Pada $\mathrm{t}+1$, abnormal return mulai menurun, namun masih berada pada level positif. Hasil yang cukup mengejutkan terjadi pada $\mathrm{t}+2$, di mana abnormal return yang bernilai negatif signifikan kembali terjadi. Meski begitu, hal ini diduga disebabkan oleh faktor lain di luar variabel penelitian. Pada tanggal 29 Juli 2016, mayoritas bursa saham di Asia, termasuk di Indonesia bergerak melemah setelah investor kecewa dengan keputusan pelonggaran stimulus yang dilakukan oleh Bank of Japan. Pada hari itu, IHSG ditutup anjlok $1,57 \%$ atau 83,22 poin ke level 5.215,99. Indeks negara lain juga mengalami nasib yang sama, seperti FTSE Straits Time Singapura yang tercatat merosot $1,67 \%$, indeks FTSE Malaysia $\mathrm{KLCl}$ melemah 0,32\%., indeks Kospi Korea Selatan melemah 0,24\%, dan indeks Shanghai Composite melemah $0,50 \%$. Apabila peristiwa ini tidak terjadi, rata-rata abnormal return saham dimungkinkan tetap berada pada nilai positif. 
Tabel 4. Hasil Perhitungan Paired Sample t-test pada Average Abnormal Return Sebelum dan Sesudah Peristiwa

\begin{tabular}{lrr}
\hline & \multicolumn{1}{c}{ Variable 1 } & \multicolumn{1}{c}{ Variable 2 } \\
\hline Mean & -0.076495546 & 0.01415883 \\
Variance & 0.121455703 & 0.115217734 \\
Observations & 38 & 38 \\
Pearson Correlation & 0.055429181 & \\
Hypothesized Mean Difference & 0 & \\
df & 37 & \\
t Stat & -1.18190923 & \\
P(T<=t) one-tail & 0.12239114 & \\
t Critical one-tail & 1.687093597 & \\
P(T<=t) two-tail & 0.24478228 & \\
t Critical two-tail & 2.026192447 & \\
\hline
\end{tabular}

Sementara itu, abnormal return yang positif dan signifikan secara statistik kembali terjadi pada $\mathrm{t}+3$. Hal tersebut merupakan respon pelaku pasar terhadap pelaksanaan rapat pimpinan untuk membahas membahas tax amnesty yang dilaksanakan oleh Sri Mulyani bersama dengan Direktur Jenderal Pajak Ken Dwijugiasteadi di Kantor Direktorat Jenderal Pajak pada hari Sabtu, 30 Juli 2016.Rapat koordinasi tersebut merupakan bukti keseriusan Sri Mulyani sebagai Menteri Keuangan baru dalam menjalankan salah satu tugas beratnya, yakni menyukseskan program tax amnesty. Tercapainya tujuan dari program tax amnesty dapat mendorong pembangunan infrastruktur di Indonesia. Oleh karena itu, pasar modal menyambut baik kinerja kabinet hasil reshuffle, khususnya Sri Mulyani sebagai Menteri Keuangan.

\section{Pengujian Hipotesis 2}

Pengujian ini dilakukan untuk mengetahui apakah terdapat abnormal return yang secara signifikan lebih positif pada periode setelah peristiwa pelantikan Kabinet Kerja hasil reshuffle jilid II. Perbedaan rata-rata abnormal return selama 5 hari sebelum peristiwa dan 5 hari setelah peristiwa dianalisis menggunakan paired sample t-test. Tabel 4 menyajikan hasil pengujian yang telah dilakukan.

Berdasarkan hasil perhitungan, rata-rata abnormal return pada periode setelah peristiwa lebih positif jika dibandingkan dengan rata-rata abnormal return pada periode sebelum peristiwa. Untuk menguji apakah terdapat perbedaan rata-rata abnormal return yang signifikan pada periode sebelum dan setelah peristiwa, maka dilakukan $t$-test paired sample for two means menggunakan Microsoft Excel dengan $\alpha 5 \%$.

Berdasarkan hasil pengujian, diperoleh $p$ value pada one tailed-test sebesar 0,12239. Nilai $p$ value lebih besar dari $\alpha(0,05)$, sehingga hipotesis nul gagal ditolak. Oleh karena itu, hipotesis alternatif yang menyatakan bahwa terdapat abnormal return yang lebih positif secara signifikan pada periode setelah peristiwa dinyatakan ditolak. Hasil penelitian ini sejalan dengan penelitian yang dilakukan Primastono (2006), 
di mana hasil penelitian menunjukkan bahwa tidak terdapat perbedaan rata-rata abnormal return yang signifikan pada periode sebelum dan setelah peristiwa pengumuman Kabinet Gotong Royong. Tidak adanya perbedaan yang signifikan antara rata-rata abnormal return sebelum dan sesudah peristiwa ini membuktikan meskipun peristiwa pengumuman kabinet mengandung muatan informasi, namun reaksi para investor tidak sampai menimbulkan gejolak yang luar biasa bagi pasar modal. Penelitian lain yang dilakukan oleh Sianturi (2005) menunjukkan hasil yang berbeda. Hasil penelitian menunjukkan bahwa terdapat perbedaan rata-rata abnormal return pada periode sebelum dan setelah peristiwa pelantikan presiden dan pengumuman kabinet pada tanggal 20 Oktober 2004.

Rata-rata abnormal return pada periode sebelum dan setelah peristiwa ada penelitian ini tidak berbeda secara signifikan karena meski di satu sisi publik menyambut positif keputusan Jokowi untuk memasukkan nama Sri Mulyani dalam Kabinet Kerja hasil reshuffle jilid II, di sisi lain publik merasa kecewa dengan pencopotan Ignasius Jonan dan Anies Baswedan yang dianggap memiliki kinerja cukup baik dan bertahannya Puan Maharani yang kinerjanya dinilai biasa saja. Kekecewaan publik bertambah seiring dengan munculnya anggapan bahwa Presiden Jokowi melakukan "bagi-bagi jatah kursi" di Kementerian. Hal ini dapat dilihat dari diangkatnya Airlangga Hartarto dari Partai Golkar menjadi Menteri Perindustrian dan Asman Abnur dari Partai Amanat Nasional menjadi Menteri Pendayagunaan Aparatur Negara dan Reformasi Birokrasi.
Pengangkatan kedua tokoh tersebut dinilai merupakan balas jasa Presiden Jokowi kepada Partai Amanat Nasional yang menyeberang ke Koalisi Merah Putih pada bulan September 2015, dan Partai Golkar pada November 2015, setelah sebelumnya kedua partai tersebut bergabung dalam Koalisi Indonesia Hebat.

\section{SIMPULAN}

Hasil uji beda $\mathrm{t}$ satu sisi menunjukkan bahwa abnormal return positif yang signifikan secara statistik terjadi pada event day ( $\mathrm{t}$ ) dan $\mathrm{t}+3$. Abnormal return positif signifikan pada event day merepresentasikan bahwa pasar menganggap peristiwa pelantikan Kabinet Kerja hasil reshuffle jilid II merupakan good news, sehingga disambut dengan baik oleh pelaku pasar, sedangkan abnormal return positif signifikan pada $\mathrm{t}+3$ terjadi sebagai respon positif pasar kepada kinerja menteri baru yang dinilai cukup cepat.

Hasil uji beda rata-rata (one-paired sample t-test) menunjukkan tidak terdapat perbedaan rata-rata abnormal return yang signifikan pada periode sebelum dan setelah peristiwa. Penyebabnya karena meski di satu sisi publik menyambut positif keputusan Jokowi untuk memasukkan nama Sri Mulyani dalam Kabinet Kerja hasil reshuffle jilid II, di sisi lain publik merasa kecewa dengan pencopotan menteri yang kinerjanya cukup baik, adanya menteri yang tetap dipertahankan meski kinerjanya tak cukup baik, serta adanya anggapan bahwa Presiden Jokowi melakukan "bagi-bagi jatah kursi" di Kementerian. 


\section{DAFTAR PUSTAKA}

Asri, M. (1996). U.S. Multinational's Stock Price Reaction to Host Country's Government Change: The Case of Prime Minister Takeshita's Resignation. Kelola, V (11), 126-137.

Bodie, Z., et.al. (2011). Investments and Portfolio Management ( $9^{\text {th }}$ Edition). New York: McGraw-Hill.

Brown, S. \& Warner, J.B. (1985). Using Daily Stock Return (The Caseof Event Studies). Journal of Financial Economics, 14 (1), 331.

Chandra, T. (2013). The Impact of Fuel Price Increase on Stock Price in Indonesia Stock Exchange. Journal of Economics, Business, and Accountancy Ventura, 16 (3), 385-398.

Fama, E.F. (1970). Efficient Capital Market: A Review of Theory and Empirical Work. The Journal of Finance, 25(2), 383-417.

Hartono, J. (2010). Studi Peristiwa: Menguji Reaksi Pasar Modal Akibat Suatu Peristiwa. Yogyakarta: BPFE.

Hartono, J. (2014). Teori Portfolio dan Analisis Investasi.Edisi Ketujuh. Yogyakarta: BPFE.

Husnan, S. (2008). Manajemen Keuangan: Teori dan Penerapan. Edisi Keempat. Yogyakarta: BPFE.

Indonesia Central Securities Depository. (2016). Pengumuman Corporate Action. Diakses dari http://www.ksei.co.id/ publications/corporate-action-schedules pada tanggal 5 Oktober 2016.

Indonesia Stock Exchange. (2016). Ringkasan Harga Saham. Diakses dari http://www.idx.co.id/idid/beranda/unduhdata/ringkasan. aspx/ pada tanggal 4 Oktober 2016.

Keselman, H.J., Wilcox, R.R., \& Othman, A.R. (2002). Trimming, Transforming Statistics, and Bootstrapping:
Circumventing the Biasing Effects of Heterescedascityand Nonnormality. Journal of Modern Applied Statistical Methods, 1(2), 288-309.

Kim, T. (2015). T-test as a Parametric Statistic. Korean Journal of Anesthesiology, 68 (6), 540-546.

McWilliams A. \& Siegel, D. (1997). Event Studies in Management Research: Theoretical and Empirical Issues. Academy of Management Journal, 40 (3), 626-657.

Nimkhunthod, W. (2007). An Impact of Political Events on the Stocks Exchange in Thailand. Thesis. Master Of Science Program In Finance Faculty Of Commerce And Accountancy Thammasat University.

Nippani, Srivinas, \& Augustine C. Arize. (2005). US Presidential Election Impact on Canadian and Mexican Stock Markets. Journals of Economic and Finance, 29(2), 271-279.

Primastono, I. (2006). Analisis Perbandingan Peristiwa Pengumuman Kabinet Gotong Royong Dan Kabinet Indonesia Bersatu Terhadap Reaksi Harga Saham Dan Likuiditas Saham. Tesis. Magister Manajemen Universitas Diponegoro.

Rahayu, E.W. (2007). Reaksi Pasar Modal terhadap Pengumuman Perombakan (Reshuffle) Terbatas Kabinet Indonesia Bersatu Studi Empiris pada PerusahaanPerusahaan yang terdaftar di Bursa Efek Jakart (BEJ). Jurnal Akuntansi Universitas Sanata Dharma, 9 (2), 129-142.

Sianturi, T.S. (2005). Reaksi Pasar Modal Terhadap Hasil Pemilihan Umum dan Pergantian Pemerintahan Tahun 2004. Tesis. Magister Sains Eksekutif Akuntansi Universitas Gadjah Mada.

Strong, R.A. (2001). Practical Investment Management. Edisi Kedua. Australia: South-Wester College Publishing. 
Suryawijaya, M.A. \& Setiawan, F.A. (1998). Reaksi Pasar Modal Indonesia Terhadap Peristiwa Politik Dalam Negeri (Event Study Pada Peristiwa 27 Juli 1996). Kelola, VII (18), 137-153.
Tandelilin, E. (2010). Portofolio dan Investasi. Edisi Pertama. Yogyakarta: Kanisius. 